\title{
ONCOLOGICAL OUTCOMES OF LAPAROSCOPIC RADICAL NEPHRECTOMY FOR RENAL CANCER
}

\author{
Jose R. Colombo Jr., Georges-Pascal Haber, Monish Aron, Marcello Cocuzza ${ }^{\text {, }}$
} Ricardo Colombo, Jihad Kaouk, Inderbir S. Gill

Colombo Jr. JR, Haber GP, Aron M, Cocuzza M, Colombo R, Kaouk J, Gill IS. Oncological outcomes of laparoscopic radical nephrectomy for renal cancer carcinoma. Clinics. 2007;62(3):251-6.

PURPOSE: To report the 5-year oncological outcomes of patients undergoing laparoscopic radical nephrectomy for renal cancer compared to a cohort of patients undergoing open radical nephrectomy.

METHODS: We retrospectively analyzed the data of 88 patients undergoing radical nephrectomy for renal cell carcinoma prior to January 2000. Of these, 45 patients underwent laparoscopic radical nephrectomy, and 43 patients underwent open radical nephrectomy. Inclusion criteria comprised clinically organ-confined tumors of $15 \mathrm{~cm}$ or less in size without concomitant lymphadenopathy or vena cava thrombus. Oncological follow-up data were obtained from charts, radiological reports, and phone calls to patients or their families, and were calculated from the date of surgery to the date of last appointment with physician or date of death.

RESULTS: All laparoscopic procedures were completed without open conversion. On comparing the laparoscopic radical nephrectomy and open radical nephrectomy groups, mean tumor size was 5.8 vs $6.2 \mathrm{~cm}(P=.44)$, mean blood loss was 183 vs 461 $\mathrm{mL}(P=.004)$, and mean operative time was 2.8 vs $3.7 \mathrm{hrs}(P<.001)$. Over a mean follow-up of 5 years in the laparoscopic radical nephrectomy group and 6 years in the open radical nephrectomy group, the overall survival was $81 \%$ vs $79 \%(P=.47)$, and cancer-specific survival was $90 \%$ vs $92 \%(P=.70)$, respectively.

CONCLUSIONS: Laparoscopic radical nephrectomy for renal cancer confers equivalent 5-year oncological outcomes to those of open surgery.

KEYWORDS: Cancer. Laparoscopy. Radical nephrectomy. Outcomes. Survival.

\section{INTRODUCTION}

The surgical management of renal mass has changed significantly in the last decade. The oncological principles of open radical nephrectomy (ORN) are duplicated with the laparoscopic approach, but with lower morbidity; therefore, the laparoscopic approach is now considered the standard

Section of Laparoscopic and Robotic Surgery Glickman Urological Institute, Cleveland Clinic, Cleveland, Ohio

a - Division of Urology, University of Sao Paulo Medical School, Sao Paulo, SP, Brazil.

Email: betocolombo@hotmail.com

Received for publication on November 21,2006.

Accepted for publication on December 26, 2006. of care when nephron-sparing surgery cannot be performed. ${ }^{1}$ Herein, we present the 5-year oncological outcomes of laparoscopic radical nephrectomy (LRN) compared with a contemporary series of open radical nephrectomy from a single institution.

\section{METHODS}

Patients undergoing radical nephrectomy for renal cell carcinoma were retrospectively analyzed with Institutional Review Board approval. The inclusion criteria for this study comprised patients with renal tumor $\leq 15 \mathrm{~cm}$ in largest dimension without any radiological evidence of vena cava involvement, local perinephric extension, or lymph node enlargement. Of the patients who fit the selection criteria, com- 
plete data were available for 88 patients. Laparoscopic radical nephrectomy was performed in 45 patients, and ORN was performed in 43 patients. Routine preoperative radiographic imaging included chest x-ray and abdominal CT or MRI scan. For patients undergoing LRN, data were prospectively entered and maintained in our radical nephrectomy registry.

Demographic data is presented in Table 1. In the LRN group, 29 (64\%) patients were men, mean age was $59 \pm$ 12 yrs, tumor size was $5.8 \pm 2.5 \mathrm{~cm}$, and the right kidney was involved in $25(55 \%)$ patients. In this group, the retroperitoneoscopic approach was employed in $36(80 \%)$ procedures. In the ORN group, $33(76 \%)$ patients are men, and mean age was $60 \pm 11 \mathrm{yrs}$.

Table 1 - Baseline and intraoperative data

\begin{tabular}{llll}
\hline & Laparoscopic & Open & $P$ value \\
\hline $\mathrm{n}$ & 45 & 43 & - \\
Male sex (\%) & $29(64)$ & $33(76)$ & .29 \\
Age (yrs)* & $59 \pm 12$ & $60 \pm 11$ & .68 \\
Tumor size (cm)* & $5.8 \pm 2.5$ & $6.2 \pm 2.5$ & .44 \\
Right side (\%) & $25(55)$ & $24(55)$ & .81 \\
Retroperitoneal & & & \\
approach (\%) & $36(80)$ & - & - \\
Clinical stage & & & .17 \\
T1 & $36(80 \%)$ & $29(67 \%)$ & \\
T2 & $9(20 \%)$ & $14(33 \%)$ & \\
Blood loss (mL)* & $183 \pm 230$ & $461 \pm 396$ & .004 \\
Hospital stay (days)* & $1.4 \pm 0.8$ & $3.9 \pm 2.7$ & $<.001$ \\
\hline
\end{tabular}

* Mean \pm standard deviation

The employed laparoscopic technique for radical nephrectomy has been described previously. ${ }^{1}$ Briefly, during the retroperitoneal approach, a working space is created with balloon dilation, and a 3-port technique is utilized. The renal hilum is dissected to isolate and control the renal artery and vein sequentially. The kidney is dissected outside the intact Gerota's fascia. Concomitant adrenalectomy is performed in patients with an upper pole tumor or with radiographic evidence of adrenal involvement. With the transperitoneal approach, a 4-port technique is utilized. The overlying bowel is reflected medially, and the major renal vessels are dissected, individually clipped, and divided. In either approach, the entrapped specimen is extracted intact through a muscle-splitting, low Pfannenstiel incision without morcellation. The open approach for radical nephrectomy was performed according to well-established techniques. In addition, residents and/or fellows-in-training were assisting the staff surgeon in all cases for both approaches.

Follow-up data were obtained from charts, radiographic reports, and direct phone calls to patients or patient's families, and were calculated from date of surgery to date of last appointment with physician or date of death.

The laparoscopic and open radical nephrectomy groups were compared using $t$ test or Wilcoxon rank sum test (for continuous variables) and chi-square or Fisher exact test (for categorical variables). Kaplan-Meier survival analysis was used to estimate the overall and cancer-specific survival. Comparisons were made for these survival estimates among the patients having open surgical and laparoscopic approaches. Cox regression models were used to assess the effect of surgery type after adjusting for age and tumor size.

\section{RESULTS}

All 45 LRN were completed without open conversion or perioperative mortality. On comparing LRN and ORN groups, blood loss was $183 \pm 230 \mathrm{~mL}$ vs $461 \pm 396 \mathrm{~mL}$ ( $P$ $<.001)$, mean operative time was $2.8 \pm 0.8$ hrs vs $3.5 \pm 1.5$ hrs $(P<.01)$, and mean hospital stay was 1.4 days (range, $1-6$ days) vs 3.9 days (range, $3-10$ days) $(P<.001)$, respectively. Concomitant adrenalectomy was performed in 31 cases $(70 \%)$ in the LRN group vs $28(65 \%)$ in the ORN group $(P=.51)$. Postoperative complications occurred in 3 patients (7\%): prolonged ileus, wound dehiscence, and deep vein thrombosis in 1 patient each. Final histopathology data regarding tumor type and stage according to the American Joint Committee on Cancer from 2002 are presented in Table 2. Pathological stage was $\leq$ pT2 in $88 \%$ of patients in the LRN group and $86 \%$ of patients in the ORN group. Positive surgical margins for cancer were found in 1 patient in the LRN group and none in the ORN group.

Mean follow-up for the LRN group was 60 months (1991months). On final analysis, 37 patients were alive and 8 had died; 4 from the renal malignancy. Thus, 5 -year over-

Table 2 - Histology and pathological stage

\begin{tabular}{llll}
\hline & Laparoscopic & Open & $P$ value \\
\hline Histology & & $37(86 \%)$ & .96 \\
Clear Cell & $37(82 \%)$ & $6(14 \%)$ & .21 \\
Papillary & $8(18 \%)$ & & \\
Pathological stage $(\%)$ & & $16(37 \%)$ & \\
pT1a & $19(42 \%)$ & $16(37 \%)$ & \\
pT1b & $18(40 \%)$ & $5(12 \%)$ & .17 \\
pT2 & $3(6 \%)$ & $5(12 \%)$ & \\
pT3a & $2(5 \%)$ & $1(2 \%)$ & \\
pT3b & $2(5 \%)$ & Zero & \\
pT4 & $1(2 \%)$ & $4(9 \%)$ & \\
Tumor grade $(\%)$ & & $24(56 \%)$ & \\
Grade 1 & $11(24 \%)$ & $11(26 \%)$ & \\
Grade 2 & $22(49 \%)$ & $4(9 \%)$ & \\
Grade 3 & $7(16 \%)$ & $28(65 \%)$ & \\
Grade 4 & $5(11 \%)$ & $2(4 \%)$ & \\
Concomitant & $31(70 \%)$ & Zero & \\
adrenalectomy $(\%)$ & & & \\
Multifocal tumors $(\%)$ & $1(2 \%)$ & $1(2 \%)$ & \\
Positive margin & & & \\
\hline & & &
\end{tabular}


all and cancer-specific survival was $81 \%$ and $90 \%$, respectively. At last follow-up, all patients that were alive had no evidence of metastatic disease; and 1 patient $(2 \%)$ had developed a local recurrence in the renal fossa. This patient had a pT4 stage (tumor was invading the psoas muscle). The patients with metastatic kidney cancer had a mean survival of 25.2 months, while the patients who died from other causes had a mean survival of 31.5 months.

In the ORN group, the mean follow-up was 72 months (15-96 months). At last follow-up, 32 patients were alive, and 11 patients died in this period: 3 from metastatic kidney cancer and 8 from other causes. The 5-year overall and cancer-specific survival was $79 \%$ and $92 \%$, respectively. The patients who died from metastatic cancer had an average survival of 17.3 months (11-22 months), and the patients who died from non-cancer causes had a survival of 35.3 months (8-60 months).

Survival data were also evaluated according to clinical stage. For T1 tumors $(<7 \mathrm{~cm})$, on comparing LRN $(\mathrm{n}=36)$ vs ORN $(n=29)$ groups, the 5-year outcomes were similar regarding cancer-specific survival $(97 \%$ vs $96 \%$, log rank = 0.89 ) and overall survival ( $85 \%$ vs $79 \%$, log rank $=0.26$ ). Similarly for pT2 tumors, the cancer-specific survival $(66 \%$ vs. $85 \%, \log$ rank $=0.37)$ and overall survival $(66 \%$ vs $78 \%$, $\log$ rank $=0.64)$ were also comparable between groups.

Table 3 - Cox regression model to assess the effect of surgery type after adjusting for age and tumor size

\begin{tabular}{lll}
\hline $\begin{array}{l}\text { Variable } \\
\text { Overall }\end{array}$ & $\begin{array}{l}\text { Hazard ratio } \\
(95 \% \text { confidence interval })\end{array}$ & $P$ value \\
\hline Laparoscopic surgery & $1.613(0.693,3.757)$ & .27 \\
Age & $1.712(1.189,2.464)$ & .004 \\
Tumor size & $1.115(0.976,1.274)$ & .11 \\
Patients who died from kidney cancer & \\
Laparoscopic surgery & $0.395(0.047,3.319)$ & .39 \\
Age & $0.936(0.240,3.655)$ & .92 \\
Tumor size & $0.595(0.353,1.003)$ & .05 \\
Patients who died from other cause & $0.947(0.266,3.372)$ & .93 \\
Laparoscopic surgery & $1.364(0.729,2.552)$ & 0.33 \\
Age & $1.130(0.886,1.441)$ & 0.33 \\
Tumor size &
\end{tabular}

Cox regression models did not show a significant difference between the two techniques, after adjusting for patient's age and tumor size (Table 3 ).

\section{DISCUSSION}

Since the initial report of laparoscopic nephrectomy in 1991 by Clayman, ${ }^{2}$ laparoscopic radical nephrectomy (LRN) has evolved, and in experienced hands has become the gold standard treatment for most of patients with renal cancer. The major advantages of the minimally invasive approach include lower perioperative morbidity, with less blood loss, shorter length of hospital stay, and quicker convalescence. ${ }^{1,3}$ However, long-term oncological data remain scanty in the literature (Table 4).

Dunn et al reported 60 LRNs with 1 open conversion, having a mean operative time of 5.5 hrs, mean blood loss of $170 \mathrm{~mL}$, and overall transfusion rate of $12 \%{ }^{3}$ Minor and major complications occurred in $34 \%$ and $3 \%$ of cases, respectively. Short-term oncological results were comparable to ORN, at a mean follow-up of 25 months. Chan et al presented 67 LRNs, with 1 open conversion, estimated mean blood loss of $290 \mathrm{~mL}$, mean operative time of 4.2 hrs, and hospital stay of 3.8 days. ${ }^{4}$ Overall complications occurred in $15 \%$ of cases, with a blood transfusion rate of $8 \%$. In that study, the overall survival with a mean followup of 35 months was $86 \%$.

In the series of 103 LRNs published by Ono et al with a follow-up of 29 months, the cancer-specific and overall survival was $98 \%$ and $93 \%$, respectively. ${ }^{5}$ In a multi-institutional analysis of 64 patients undergoing LRN by Portis et al, the estimated 5-year cancer-specific and overall survival was $98 \%$ and $81 \%$, respectively. ${ }^{6}$

Saika et al reported 188 LRNs, with an estimated 5year cancer-specific and overall survival of $94 \%$ and $87 \%$, respectively. ${ }^{7}$ In that series, 7 open conversions were noted, with a mean operative time of $4.6 \mathrm{hrs}$, mean blood loss of $250 \mathrm{~mL}$, and perioperative complication rate of $15 \%$.

In the recently published study of Permpongkosol et al. with a median follow-up of 73 months, the actuarial can-

Table 4 - Laparoscopic radical nephrectomy oncological outcomes

\begin{tabular}{|c|c|c|c|c|c|c|c|}
\hline Author & $\mathrm{n}$ & $\begin{array}{l}\text { Follow-up } \\
\text { (yrs) }\end{array}$ & Conversion & $\begin{array}{l}\text { Blood loss } \\
(\mathrm{mL})\end{array}$ & $\begin{array}{l}\text { Operative Time } \\
(\mathrm{hr})\end{array}$ & $\begin{array}{l}\text { Hospital stay } \\
\text { (days) }\end{array}$ & $\begin{array}{l}\text { Projected 5-year, } \\
\text { disease-free survival }\end{array}$ \\
\hline Dunn $2000^{3}$ & 44 & 2.1 & 1 & NA & 5.5 & 3.4 & $91 \%$ \\
\hline Chan2001 4 & 66 & 2.9 & 1 & 280 & 4.2 & 3.8 & $95 \%$ \\
\hline Ono2001 5 & 102 & 2.4 & 4 & 254 & 4.7 & N/A & $95 \%$ \\
\hline Portis $2002^{6}$ & 64 & 4.5 & N/A & 219 & N/A & 4.8 & $98 \%$ \\
\hline Saika2003 ${ }^{7}$ & 195 & 3.3 & 7 & 248 & 4.6 & N/A & $87 \%$ \\
\hline Permpongkosol2005 8 & 121 & 6 & 1 & 280 & 4.2 & 3.8 & $94 \% *$ \\
\hline Present Study & 45 & 5 & 0 & 179 & 2.8 & 1.4 & $92 \% *$ \\
\hline
\end{tabular}

*Actual 5-year survival. 
cer-specific and overall survival at 10 years was of $97 \%$ and $76 \%$, respectively, which was similar to that of the ORN. ${ }^{8}$

In each of the above series, the oncological outcomes of LRN were similar to ORN as evaluated by calculated 5 -year cancer-specific and overall survival.

Focusing on clinical T2 tumors at our institution, Steinberg et al compared 65 LRNs (tumor size of $9.2 \mathrm{~cm}$ ) with ORNs (tumor size of $9.9 \mathrm{~cm}$ ), with superior perioperative outcomes for blood loss, operative time, hospital stay, and convalescence for the LRN group. ${ }^{9}$

The 5-year cancer-specific survival results for $\mathrm{T} 1$ and $\mathrm{T} 2$ tumors were also not statistically different between the groups in the present study, presenting similar results with the those of the ORN series reported by Tsui et al, ${ }^{10}$ and with the series published by Frank et al from Mayo Clinic with 2746 patients. ${ }^{11}$ In addition, we did not have any contralateral recurrence, a fact that may be secondary to absence of positive margins and low incidence of multifocal tumors. As reported by Bani-Hani et al, ${ }^{12}$ these two factors are risk factors for contralateral recurrence for clear-cell renal cell carcinoma while nuclear grade was a significant predictor of contralateral recurrence for papillary renal cell carcinoma.

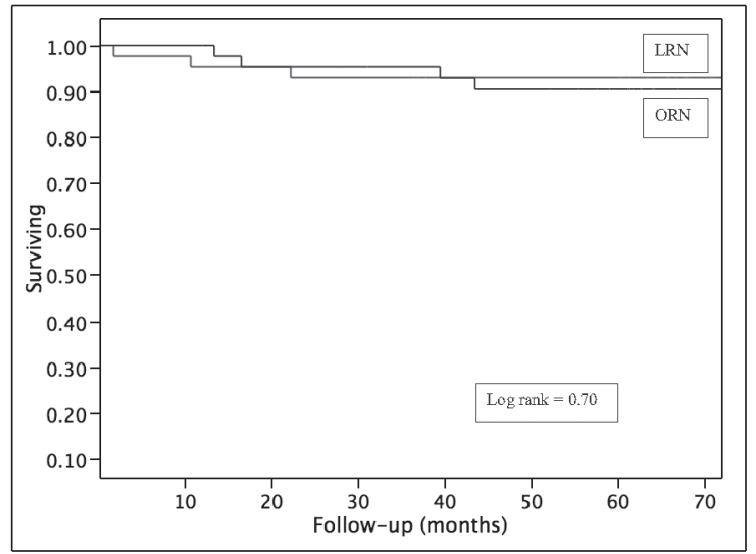

Figure 1 - Cancer-specific survival; laparoscopic radical nephrectomy (LRN) vs open radical nephrectomy (ORN).

The retroperitoneal approach is preferentially used at our institution unless relative contraindications exist, such as larger tumors $(>10 \mathrm{~cm})$ or prior retroperitoneal surgery. Nambirajan et al $^{13}$ in the first prospective, randomized controlled study found no difference between the two approaches, when the procedure was performed by an experienced laparoscopic surgeon. More recently, Desai and $\mathrm{al}^{14}$ showed no difference in the results comparing the two ap-

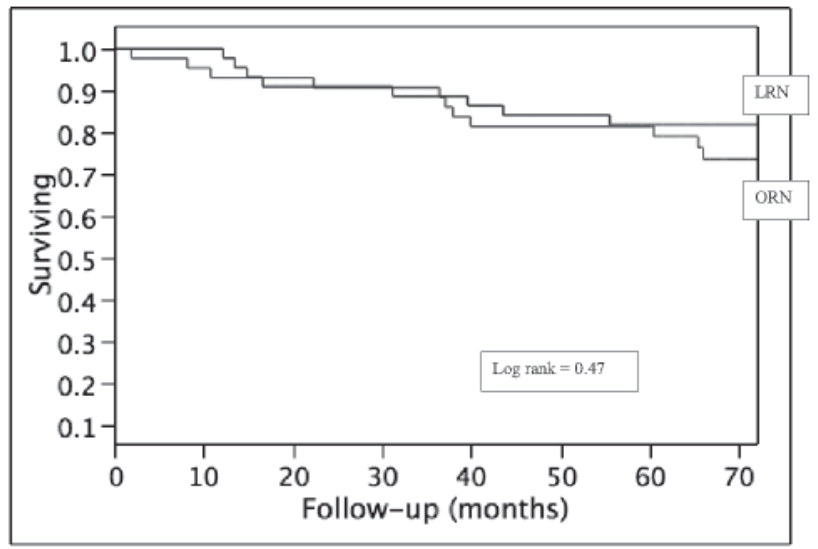

Figure 2 - Overall survival; laparoscopic radical nephrectomy (LRN) vs open radical nephrectomy (ORN).

proaches in the context of a prospective, randomized study. The specimen extraction was performed without morcellation in all cases.

We believe that relevant information from pathological analysis would be lost with morcellation, and the aesthetic advantages do not justify the morcellation, although a prospective, randomized trial has not yet been published comparing the oncological outcomes between these techniques. ${ }^{15}$

From the financial standpoint, after the initial learning curve, LRN is $12 \%$ less expensive than ORN at the authors' institution. ${ }^{16}$

The weaknesses of this study are inherent in its retrospective design, as such selection bias and lack of control. The strengths include long and reliable follow-up, and data collection for similar periods of time, minimizing the differences in renal cancer care over time. We used tumor size and age in the statistical model to control for any clinical difference between groups.

Indications for LRN are expanding in excellence centers worldwide, using the minimally invasive approach for larger tumors, patients with previous abdominal surgery, level I renal vein involvement, and cytoreductive nephrectomy. ${ }^{17,18}$ We believe that the data presented support the role of LRN as the standard treatment for renal cancer when nephron-sparing surgery is not suitable.

\section{CONCLUSION}

Our data show that laparoscopic radical nephrectomy has a low complication rate and 5-year oncological outcomes comparable to open radical nephrectomy for $\mathrm{T} 1$ and $\mathrm{T} 2$ renal cancer. 
Colombo JR Jr, Haber GP, Aron M, Cocuzza M, Colombo R, Kaouk J, Gill IS. Resultados oncológicos da nefrectomia radical laparoscópica no tratamento do carcinoma renal. Clinics. 2007;62(3):251-6.

OBJETIVO: Relatar os resultados oncológicos após 5 anos de seguimento em pacientes submetidos a nefrectomia radical laparoscópica para tratamento do câncer renal, comparando esses com os resultados obtidos com um grupo de pacientes submetidos a nefrectomia radical aberta.

MÉTODOS: Foram analisadas retrospectivamente as informações obtidas de 88 pacientes submetidos a nefrectomia radical para o tratamento do carcinoma renal realizadas previamente a Janeiro de 2000. Destes pacientes, 45 foram tratados com nefrectomia radical laparoscópica e 43 com nefrectomia radical aberta. Foram incluídos pacientes com tumores localizados com tamanho máximo de $15 \mathrm{~cm}$, sem adenopatia ou sinal de envolvimento de veia renal na avaliação radiologica pré-operatória. As informações sobre o seguimento dos pacientes foram obtidas a partir de prontuários, laudos de exames radiológicos e ligações telefônicas para pacientes e/ou familiares. O seguimento foi calculado desde a data da cirurgia até a última consulta médica ou data de falecimento.

RESULTADOS: Todos os procedimentos laparoscópicos foram realizados sem conversão para a técnica aberta. $\mathrm{O}$ tamanho médio tumoral foi de 5.8 e. $6.2 \mathrm{~cm}(\mathrm{P}=0.44)$, perda sanguínea estimada de 183 e. $461 \mathrm{~mL}(\mathrm{P}=0.004)$, e tempo operatório de 2.8 e. 3.7 horas $(\mathrm{P}<0.001)$, respectivamente para os grupos nefrectomia radical laparoscópica e nefrectomia radical aberta. $\mathrm{O}$ tempo de seguimento médio foi de 5 anos para o grupo nefrectomia radical laparoscópica e 6 anos para o grupo nefrectomia radical aberta. A sobrevida global após 5 anos foi de $81 \%$ e $79 \%$ $(\mathrm{P}=0.47)$, e a sobrevida específica para cancer foi de $90 \%$ e $92 \%(\mathrm{P}=0.70)$, para os grupos nefrectomia radical laparoscópica e nefrectomia radical aberta respectivamente. CONCLUSÃO: A nefrectomia radical laparoscópica tem resultados oncológicos em 5 anos similares a técnica convencional aberta.

UNITERMOS: Câncer renal, Laparoscopia, Nefrectomia radical, Resultados, Sobrevida

\section{REFERENCES}

1. Saranchuk JW, Savage SJ. Laparoscopic radical nephrectomy: current status. BJU Int. 2005;95 Suppl 2:21-6.

2. Clayman RV, Kavoussi LR, Soper NJ, Dierks SM, Meretyk S, Darcy MD, et al. Laparoscopic nephrectomy: initial case report. J Urol. $1991 ; 146: 278-82$

3. Dunn MD, Portis AJ, Shalhav AL, Elbahnasy AM, Heidorn C, McDougall EM, et al. Laparoscopic versus open radical nephrectomy: a 9-year experience. J Urol 2000;164:1153-9.

4. Chan DY, Cadeddu JA, Jarrett TW, Marshall FF, Kavoussi LR Laparoscopic radical nephrectomy: cancer control for renal cell carcinoma. J Urol. 2001; 166:2095-9; discussion 9-100.
5. Ono Y, Kinukawa T, Hattori R, Gotoh M, Kamihira O, Ohshima S. The long-term outcome of laparoscopic radical nephrectomy for small renal cell carcinoma. J Urol. 2001;165 (6 Pt 1):1867-70.

6. Portis AJ, Yan Y, Landman J, Chen C, Barrett PH, Fentie DD, et al. Long-term followup after laparoscopic radical nephrectomy. J Urol 2002; 167(3):1257-62.

7. Saika T, Ono Y, Hattori R, et al. Long-term outcome of laparoscopic radical nephrectomy for pathologic T1 renal cell carcinoma. Urology. 2003;62:1018-23

8. Permpongkosol S, Chan DY, Link RE, Sroka M, Allaf M, Varkarakis I, et al. Long-term survival analysis after laparoscopic radical nephrectomy. J Urol. 2005;174 (4 Pt 1):1222-5. 
9. Steinberg AP, Finelli A, Desai MM, Abreu SC, Ramani AP, Spaliviero $\mathrm{M}$, et al. Laparoscopic radical nephrectomy for large (greater than 7 cm, T2) renal tumors. J Urol. 2004;172 (6 Pt 1):2172-6.

10. Tsui KH, Shvarts O, Smith RB, Figlin RA, deKernion JB, Belldegrun A. Prognostic indicators for renal cell carcinoma: a multivariate analysis of 643 patients using the revised 1997 TNM staging criteria. J Urol. 2000;163:1090-5; quiz 295.

11. Frank I, Blute ML, Leibovich BC, Cheville JC, Lohse CM, Zincke H. Independent validation of the 2002 American Joint Committee on cancer primary tumor classification for renal cell carcinoma using a large, single institution cohort. J Urol. 2005;173:1889-92.

12. Bani-Hani AH, Leibovich BC, Lohse CM, Cheville JC, Zincke H, Blute ML. Associations with contralateral recurrence following nephrectomy for renal cell carcinoma using a cohort of 2,352 patients. J Urol. $2005 ; 173: 391-4$

13. Nambirajan T, Jeschke S, Al-Zahrani H, Vrabec G, Leeb K, Janetschek G. Prospective, randomized controlled study: transperitoneal laparoscopic versus retroperitoneoscopic radical nephrectomy. Urology. 2004;64:919-24
14. Desai MM, Strzempkowski B, Matin SF, Steinberg AP, Ng C, Meraney $\mathrm{AM}$, et al. Prospective randomized comparison of transperitoneal versus retroperitoneal laparoscopic radical nephrectomy. J Urol 2005;173:3841.

15. Novick AC. Laparoscopic radical nephrectomy: specimen extraction. BJU Int. 2005;95 Suppl 2:32-3.

16. Meraney AM, Gill IS. Financial analysis of open versus laparoscopic radical nephrectomy and nephroureterectomy. J Urol. 2002;167:175762.

17. Fenn NJ, Gill IS. The expanding indications for laparoscopic radical nephrectomy. BJU Int. 2004;94:761-5.

18. Ono Y, Hattori R, Gotoh M, Yoshino Y, Yoshikawa Y, Kamihira O. Laparoscopic radical nephrectomy for renal cell carcinoma: the standard of care already? Curr Opin Urol. 2005;15:75-8. 